\title{
Pengaruh Foot Massage terhadap Parameter Hemodinamik Non Invasif pada Pasien di General Intensive Care Unit
}

\author{
Anita Setyawati, Kusman Ibrahim, Titin Mulyati \\ Fakultas Keperawatan, Universitas Padjadjaran \\ Email : anita.setyawati@unpad.ac.id
}

\begin{abstract}
Abstrak
Kondisi hemodinamik yang tidak stabil merupakan kondisi yang biasa terjadi pada pasien di General Intensive Care Unit (GICU). Hal ini dapat disebabkan karena stresor yang berasal dari aspek fisiologis, psikologis, maupun lingkungan. Saat ini terapi yang diberikan pada pasien di GICU didominasi oleh terapi farmakologi. Sementara berdasarkan teori keperawatan holistik, asuhan perawatan pada pasien dapat dioptimalkan dengan terapi komplementer seperti foot massage. Penelitian ini bertujuan untuk mengetahui pengaruh foot massage terhadap parameter hemodinamik non invasif pada pasien di ruang GICU RSUP Dr. Hasan Sadikin Bandung. Rancangan penelitian ini menggunakan quasi experimental design dengan pendekatan time series design. Jumlah sampel yang digunakan sebanyak 33 pasien dengan teknik consecutive sampling. Data penelitian dianalisis menggunakan uji Friedman dan dilanjutkan dengan analisis Post-Hoc. Hasil penelitian menunjukkan terdapat pengaruh foot massage secara signifikan terhadap penurunan MAP $(p<0,001)$, penurunan denyut jantung $(p=0,002)$, dan penurunan frekuensi pernafasan $(p<0,001)$; namun tidak terdapat pengaruh foot massage secara signifikan terhadap peningkatan saturasi oksigen $(p=0,150)$. Foot massage dapat menimbulkan aktivitas vasomotor di medula. Aktivitas vasomotor ini dapat menurunkan resistensi perifer dan merangsang saraf parasimpatis untuk menurunkan frekuensi jantung yang selanjutnya dapat meningkatkan curah jantung sehingga membuat pengiriman dan penggunaan oksigen oleh jaringan menjadi adekuat. Oleh karena itu, diharapkan perawat dapat melakukan praktik foot massage terhadap pasien untuk melengkapi terapi farmakologi yang sudah diberikan.
\end{abstract}

Kata kunci: Foot massage, parameter hemodinamik non invasif.

\section{Effects of Foot Massages towards Non Invasive Hemodynamic Parameters of Patients in General Intensive Care Unit}

\begin{abstract}
Unstable hemodynamic condition commonly happens in General Intensive Care Unit (GICU). This is caused by stressors from physiological, psychological, and environmental stressors. Nowadays, therapies for GICU patients are dominated by pharmacological therapies. Meanwhile, holistic nursing care could be optimized using complementary therapy such as foot massages. This study aimed to identify the effects of foot massages towards non-invasive hemodynamic parameters of patients in GICU Dr. Hasan Sadikin Hospital Bandung. The research design was quasi experimental using time series design. The sample size was 33 patients who were recruited using consecutive sampling technique. The data were analysed using Friedman test and followed by Post-Hoc analysis. The results showed that there were significant effects of food massage towards the decreased of MAP $(p<0,001)$, the decreased of heart rate $(p=0,002)$, and the decreased of respiration rate $(p<0,001)$; however, there was no significant effect of foot massages towards the increased of oxygen saturation $(\mathrm{p}=0,150)$. Foot massage can create vasomotor activation in the medulla. This vasomotor activation can decrease peripheral resistances and stimulate parasympathetic nervous to decrease the heart rate which then increase cardiac output thus increase adequate oxygen supply and usage by body tissues. Therefore, it is recommended that nurses can perform foot massages for patients to complement the pharmacological therapies that has been given.
\end{abstract}

Keywords: Foot massages, non-invasive hemodynamic parameter. 
Anita Setyawati: Pengaruh Foot Massage terhadap Parameter Hemodinamik Non-Invasif

\section{Pendahuluan}

Manusia merupakan makhluk yang utuh dan unik yang terdiri dari komponen bio, psiko, sosio, dan spiritual. Hal ini berarti kebutuhan manusiajugaharus dipenuhi secarakeseluruhan atau holistik yang meliputi kebutuhan biologis, psikologis, sosial, dan spiritual baik dalam kontinum sehat maupun sakit. Menurut teori Nightingale, perawatan holistik digambarkan dengan penggunaan terapi komplementer yaitu terapi yang diberikan untuk melengkapi terapi medis konvensional. Salah satu jenis terapi komplementer yang menurut literatur banyak terbukti berpengaruh terhadap kesejahteraan bagi tubuh, yaitu foot massage (Setyoadi \& Kushariyadi, 2011).

Foot massage adalah manipulasi jaringan lunak pada kaki secara umum dan tidak terpusat pada titik-titik tertentu pada telapak kaki yang berhubungan dengan bagian lain pada tubuh (Coban \& Sirin, 2010). Manipulasi ini terdiri dari 5 teknik dasar yaitu effleurage (gosokan), petrissage (pijatan), tapotement (pukulan), friction (gerusan), dan vibration (getaran) (Haakana, 2008). Manfaat foot massage semakin jelas teridentifikasi dan dikategorikan sebagai manfaat fisik dan mental emosional (Puthusseril, 2006; Kozier et al., 2010).

Beberapa penelitian telah membuktikan manfaat foot massage secara luas, salah satunya adalah pengaruh foot massage terhadap perubahan parameter hemodinamik non invasif. Hasil penelitian Eimani dan Eshq (2004) menunjukkan bahwa foot massage dapat menurunkan mean arterial pressure (MAP), denyut jantung, dan frekuensi pernafasan. Smith, Yamashita, Bryant, Hemphill, dan Kutner (2009) mengungkapkan hasil penelitian Hayes dan Cox yang menunjukkan bahwa foot massage dapat menurunkan tekanan darah, denyut jantung, dan frekuensi oksigen. Sementara hasil penelitian Moshtaghe, Eimani, Abed, Hosseiny, dan AlaviiMajd (2004); Shaban, Amiry, Mehran, \& Kahrary (2004); dan Kaur, Kaur, \& Bhardwaj (2012) menunjukkan bahwa foot massage dapat menurunkan MAP dan denyut jantung serta meningkatkan saturasi oksigen.

Menurut Kementrian Kesehatan Republik Indonesia [Kemkes RI] (2011), Intensive Care Unit (ICU) adalah suatu bagian dari rumah sakit yang mandiri, dengan staf yang khusus dan perlengkapan yang khusus untuk observasi, perawatan, dan terapi pasien-pasien yang menderita penyakit akut, cedera, atau penyulit-penyulit yang mengancam nyawa atau potensial mengancam nyawa dengan prognosis dubia yang diharapkan masih reversibel. Merujuk pada definisi di atas, Chulay dan Burns (2006) serta Gattinoni dan Carlesso (2013) menjabarkan kondisi yang sering terjadi pada pasien di ICU adalah hemodinamik yang tidak stabil yang ditandai dengan peningkatan MAP, denyut jantung, dan frekuensi pernafasan; serta penurunan saturasi oksigen.

Peningkatan MAP pada pasien di ICU disebabkan karena peningkatan aktivitas vasomotor di medula yang menyebabkan vasokonstriksi arteriol dan meningkatkan resistensi perifer (Jevon \& Ewens, 2009). Sementara peningkatan denyut jantung dipengaruhi oleh stres, kecemasan, nyeri, kondisi yang menghasilkan kompensasi pelepasan katekolamin endogen seperti hipovolemia, demam, anemia, dan hipotensi (Chulay \& Burns, 2006). Pada kondisi disfungsi jantung, peningkatan denyut jantung dapat mengurangi waktu pengisian ventrikel yang menghasilkan penurunan volume sekuncup dan pada akhirnya membuat penurunan curah jantung. Penurunan curah jantung dapat mengakibatkan pengiriman dan penggunaan oksigen ke dalam jaringan tidak mencukupi sehingga terjadi hipoksia jaringan (Morton \& Fontaine, 2009). Hal ini ditandai dengan adanya penurunan saturasi oksigen dan peningkatan frekuensi pernafasan.

Apabila kondisi hipoksia jaringan berlangsung terus-menerus, maka dapat menyebabkan disfungsi sel dan organ yang pada akhirnya menyebabkan kematian sel atau kegagalan organ (Morton \& Fontaine, 2009). Oleh karena itu, sebagai bagian dari interdisiplin di ICU, perawat dituntut agar dapat memberikan perawatan non farmakologi yang tidak memiliki pengaruh negatif dan dapat melengkapi terapi farmakologi yang selama ini sudah diberikan dalam pengelolaan pasien di ICU (Morton \& Fontaine, 2009). Berdasarkan pertimbangan pada pemilihan terapi yang secara fisiologis dapat berpengaruh terhadap sirkulasi darah, maka terapi komplementer yang tepat diberikan oleh perawat adalah foot massage. 
Anita Setyawati: Pengaruh Foot Massage terhadap Parameter Hemodinamik Non-Invasif

Rumah Sakit Umum Pusat (RSUP) Dr. Hasan Sadikin Bandung merupakan rumah sakit pelayanan, pendidikan, dan penelitian terbesar di Jawa Barat yang memiliki sebuah ruang General Intensive Care Unit (GICU). Berdasarkan hasil pengamatan peneliti dan wawancara peneliti dengan perawat di ruang GICU, diketahui bahwa pengelolaan pasien dilakukan untuk mencapai kondisi hemodinamik yang stabil. Beberapa pasien mendapatkan terapi inotropik atau vasopresor untuk mencapai hemodinamik yang stabil serta terapi oksigen melalui ventilator dengan mode bantuan sepenuhnya dan mode bantuan sebagian.

Saat ini didapatkan belum ada penelitian mengenai foot massage di tatanan ICU di Indonesia. Sementara berdasarkan hasil penelitian di luar negeri, telah banyak dibuktikan adanya pengaruh secara signifikan yang diberikan oleh foot massage terhadap parameter hemodinamik pada pasien di ICU. Sehingga hal inilah yang mendasari penulis untuk melakukan penelitian ulangan tentang pengaruh foot massage terhadap parameter hemodinamik non invasif pada pasien di ruang GICU RSUP Dr. Hasan Sadikin Bandung.

Tujuan penelitian ini adalah untuk mengetahui pengaruh foot massage terhadap penurunan MAP, denyut jantung, dan frekuensi pernafasan, serta peningkatan saturasi oksigen.

\section{Metode Penelitian}

Penelitian ini dilakukan di ruang GICU RSUP Dr. Hasan Sadikin Bandung mulai pertengahan bulan September sampai pertengahan bulan Oktober tahun 2013. Rancangan penelitian yang digunakan adalah quasi experimental design dengan pendekatan time series design. Time series design pada penelitian ini terdiri dari satu rangkaian waktu yang terdiri dari tiga pengamatan yaitu pengamatan awal (pretest), pengamatan kedua (posttest I), dan pengamatan ketiga (posttest II). Variabel yang diamati adalah parameter hemodinamik non invasif yang terdiri dari MAP, denyut jantung, frekuensi pernafasan, dan saturasi oksigen.

Pada pertama kali, parameter hemodinamik non invasif diamati dan dicatat sebagai data awal (pretest). 30 menit kemudian, parameter hemodinamik non invasif diamati kembali dan dicatat sebagai data setelah pengamatan kontrol (posttest I). Selanjutnya pasien dilakukan foot massage selama 30 menit. Setelah itu, parameter hemodinamik non invasif diamati kembali dan dicatat sebagai data setelah perlakuan foot massage (posttest II). Rancangan penelitian dijelaskan pada bagan 1 .

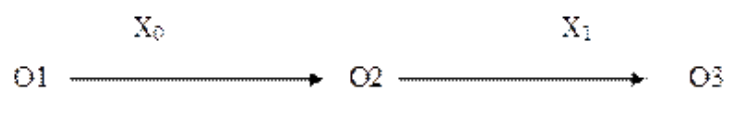

Bagan 1 Rancangan Penelitian

Keterangan :

X0 : Kontrol selama 30 menit

$\mathrm{X} 1$ : Perlakuan foot massage selama 30 menit

$\mathrm{O} 1$ : Pengamatan parameter hemodinamik non invasif pretest

O2 : Pengamatan parameter hemodinamik non invasif posttest I

O3 : Pengamatan parameter hemodinamik non invasif posttest II

Populasi pada penelitian ini adalah semua pasien di ruang GICU RSUP Dr. Hasan Sadikin Bandung. Pemilihan sampel dilakukan dengan teknik non probability sampling berupa consecutive sampling. Penentuan jumlah pasien merujuk pada penelitian sebelumnya dengan judul "Effect of Foot Massage and Reflexology on Physiological Parameters of Critically Ill Patients" oleh Kaur, Kaur, dan Bhardwaj (2012) yang dilakukan pada 60 pasien dan memiliki standar deviasi sebesar 17,2. Berdasarkan perhitungan rumus, maka jumlah pasien pada penelitian ini adalah 33 pasien.

Kriteria Inklusi :

1. Pasien yang menggunakan ventilator mode kontrol sebagian sehingga frekuensi pernafasan yang dihasilkan merupakan usaha nafas spontan pasien.

2. Pasien yang memiliki MAP $>70 \mathrm{mmHg}$, denyut jantung $>60$ kali per menit, frekuensi pernafasan $>12$ kali per menit, dan saturasi oksigen $\leq 100 \%$ karena tujuan penelitian ini untuk mengetahui penurunan MAP, denyut jantung, dan frekuensi pernafasan, serta peningkatan saturasi oksigen.

3. Pasien yang sudah tidak mendapatkan sedasi dan / atau muscle relaxant.

Kriteria Eksklusi :

1. Pasien yang mengalami fraktur, trauma, 
atau luka pada kaki.

2. Pasien dalam kondisi gelisah.

3. Pasien yang mempunyai manifestasi gejala trombosis vena dalam.

Kriteria Drop Out :

Pasien mengalami perburukan klinis pada saat diberi perlakuan foot massage karena pasien di ICU rentan tidak stabil. Namun demikian, sebelum dilakukan penelitian, peneliti telah mempertimbangkan kondisi pasien yang memungkinkan untuk dilakukan foot massage.

Data yang diperoleh pada penelitian ini dilakukan pengujian distribusi normal data terlebih dahulu menggunakan uji ShapiroWilk. Berdasarkan uji Shapiro-Wilk diketahui bahwa data yang berdistribusi normal adalah data frekuensi pernafasan, sementara data yang tidak berdistribusi normal adalah data MAP, denyut jantung, dan saturasi oksigen. Selanjutnya data dianalisis menggunakan analisis bivariat sebagai berikut.

Pertama, data dianalisis menggunakan uji Friedman karena data tidak berdistribusi normal. Analisis ini bertujuan untuk menguji perbedaan parameter hemodinamik non invasif pada pretest, posttest I, dan posttest II. Kedua, data dilanjutkan dengan analisis Post-Hoc menggunakan uji Wilcoxon untuk mengetahui kelompok mana yang berbeda secara signifikan, antara kelompok pretest posttest I dengan kelompok posttest $\mathrm{I}$ - posttest II. Ketiga, data dilanjutkan dengan analisis Post-Hoc menggunakan uji Mann-Whitney untuk menguji perbedaan antara perubahan $(\Delta)$ pretest - posttest I dengan perubahan $(\Delta)$ posttest I - posttest II. Hasil pada ketiga analisis dikatakan signifikan apabila $p<0,05$.

\section{Hasil Penelitian}

Hasil penelitian ini ditampilkan pada tabel 1, tabel 2 dan tabel 3. Tabel 1 menunjukkan hasil uji Friedman yang digunakan untuk menguji perbedaan parameter hemodinamik non invasif pada pretest, posttest I, dan posttest II. Berdasarkan hasil uji Friedman didapatkan bahwa terdapat perbedaan rerata MAP secara signifikan $(p<0,001)$; perbedaan rerata denyut jantung secara signifikan $(p=0,012)$; perbedaan rerata frekuensi pernafasan secara signifikan $(p<0,001)$; dan tidak terdapat perbedaan rerata saturasi oksigen secara signifikan $(p=0,150)$ pada ketiga pengamatan.

Tabel 2 menunjukkan hasil analisis Post-Hoc menggunakan uji Wilcoxon yang bertujuan untuk menguji perbedaan parameter hemodinamik non invasif antara kelompok pretest - posttest I dengan kelompok posttest I - posttest II. Hasil Uji Wilcoxon menunjukkan:

1. Terdapat perbedaan rerata MAP secara signifikan antara pretest dan posttest I $(p=0,001)$ serta antara posttest I dan posttest II $(\mathrm{p}<0,001)$. Perbedaan tersebut menunjukkan terdapat peningkatan rerata MAP dari pretest ke posttest I dan penurunan rerata MAP dari posttest I ke posttest II. Dengan demikian, dapat diidentifikasi bahwa terdapat pengaruh foot massage secara signifikan terhadap penurunan MAP.

2. Terdapat perbedaan rerata denyut jantung secara signifikan antara posttest I dan posttest II $(\mathrm{p}=0,002)$. Perbedaan tersebut menunjukkan terdapat penurunan rerata denyut jantung dari posttest I ke posttest II. Dengan demikian, dapat diidentifikasi bahwa terdapat pengaruh foot massage secara signifikan terhadap penurunan denyut jantung.

3. Terdapat perbedaan rerata frekuensi pernafasan secara signifikan antara posttest I dan posttest II $(\mathrm{t}=6,197 ; \mathrm{p}<0,001)$. Perbedaan tersebut menunjukkan terdapat penurunan rerata frekuensi pernafasan dari

Tabel 1 Perbedaan Rerata Parameter Hemodinamik Non Invasif pada Pretest, Posttest I, dan Posttest II (n=33)

\begin{tabular}{lcccccccc}
\hline \multirow{2}{*}{$\begin{array}{l}\text { Parameter Hemodinamik } \\
\text { Non Invasif }\end{array}$} & \multicolumn{2}{c}{ Pretest } & \multicolumn{2}{c}{ Posttest I } & \multicolumn{2}{c}{ Posttest II } \\
\cline { 2 - 6 } & Rerata & SD & Rerata & SD & Rerata & SD & 9,96 \\
\hline MAP & 92,00 & 12,87 & 96,33 & 11,46 & 90,18 & $<0,001$ \\
Denyut Jantung & 100,12 & 13,81 & 100,39 & 12,02 & 96,91 & 13,26 & 0,012 \\
Frekuensi Pernafasan & 21,21 & 5,11 & 21,21 & 4,53 & 19,03 & 4,40 & $<0,001$ \\
Saturasi Oksigen & 98,30 & 1,40 & 98,18 & 1,55 & 98,39 & 1,41 & 0,150 \\
\hline
\end{tabular}


Anita Setyawati: Pengaruh Foot Massage terhadap Parameter Hemodinamik Non-Invasif

Tabel 2 Perbedaan Rerata Parameter Hemodinamik Non Invasif antara Pretest dan Posttest I serta antara Posttest I dan Posttest II $(\mathrm{n}=33)$

\begin{tabular}{|c|c|c|c|c|c|}
\hline \multicolumn{2}{|c|}{$\begin{array}{l}\text { Parameter Hemodinamik Non } \\
\text { Invasif }\end{array}$} & \multirow{2}{*}{$\begin{array}{c}\text { Rerata } \\
92,00\end{array}$} & \multirow{2}{*}{$\begin{array}{c}\text { SD } \\
12,87\end{array}$} & \multirow{2}{*}{$\begin{array}{c}\mathbf{z w} \\
3,44\end{array}$} & \multirow{2}{*}{$\begin{array}{c}\mathbf{p} \\
0,001\end{array}$} \\
\hline MAP & Pretest & & & & \\
\hline & Posttest I & 96,33 & 11,46 & & \\
\hline & Posttest I & 96,33 & 11,46 & 3,93 & $<0,001$ \\
\hline & Posttest II & 90,18 & 9,96 & & \\
\hline \multirow[t]{4}{*}{ Denyut Jantung } & Pretest & 100,12 & 13,81 & 0,86 & 0,389 \\
\hline & Posttest I & 100,39 & 12,02 & & \\
\hline & Posttest I & 100,39 & 12,02 & 3,05 & 0,002 \\
\hline & Posttest II & 96,91 & 13,26 & & \\
\hline \multirow{4}{*}{$\begin{array}{l}\text { Frekuensi } \\
\text { Pernafasan }\end{array}$} & Pretest & 21,21 & 5,11 & $<0,001$ & 1,000 \\
\hline & Posttest I & 21,21 & 4,53 & & \\
\hline & Posttest I & 21,21 & 4,53 & 6,197 & $<0,001$ \\
\hline & Posttest II & 19,03 & 4,40 & & \\
\hline \multirow[t]{4}{*}{ Saturasi Oksigen } & Pretest & 98,30 & 1,40 & 1,07 & 0,285 \\
\hline & Posttest I & 98,18 & 1,55 & & \\
\hline & Posttest I & 98,18 & 1,55 & 1,61 & 0,108 \\
\hline & Posttest II & 98,39 & 1,41 & & \\
\hline
\end{tabular}

Tabel 3 Perbedaan antara Perubahan ( $\Delta)$ Pretest - Posttest I dengan Perubahan ( $\Delta)$ Posttest I Posttest II pada Parameter Hemodinamik Non Invasif $(\mathbf{n}=\mathbf{3 3})$

\begin{tabular}{llccc}
\hline \multicolumn{1}{c}{ Parameter Hemodinamik Non Invasif } & Rerata & SD & p \\
\hline \multirow{2}{*}{ MAP } & $\Delta$ Pretest - Posttest I & 4,33 & 7,03 & $<0,001$ \\
Denyut Jantung & $\Delta$ Posttest I - Posttest II & $-6,15$ & 7,73 & 0,003 \\
\multirow{2}{*}{ Frekuensi Pernafasan } & $\Delta$ Pretest - Posttest I & 0,36 & 5,83 & $<0,001$ \\
& $\Delta$ Posttest I - Posttest II & $-3,58$ & 6,27 & \\
\multirow{2}{*}{ Saturasi Oksigen } & $\Delta$ Pretest - Posttest I & 0 & 2,53 & 0,049 \\
& $\Delta$ Posttest I - Posttest II & $-2,21$ & 2,03 & \\
\hline
\end{tabular}

posttest I ke posttest II. Dengan demikian, dapat diidentifikasi bahwa terdapat pengaruh foot massage secara signifikan terhadap penurunan frekuensi pernafasan.

4. Tidak terdapat perbedaan secara signifikan pada rerata saturasi oksigen antara pretest dan posttest $\mathrm{I}(p=0,285)$ dan antara posttest I dan posttest II $(p=0,108)$. Dengan demikian, dapat diidentifikasi bahwa tidak terdapat pengaruh foot massage secara signifikan terhadap peningkatan saturasi oksigen.

Tabel 3 menunjukkan hasil analisis PostHoc menggunakan uji Mann-Whitney yang bertujuan untuk menguji perbedaan parameter hemodinamik non invasif antara perubahan $(\Delta)$ pretest - posttest I dengan perubahan $(\Delta)$ posttest I - posttest II. Berdasarkan hasil uji Mann-Whitney diketahui bahwa terdapat perbedaan secara signifikan antara : (1) perubahan $(\Delta)$ pretest - posttest I dengan perubahan $(\Delta)$ posttest $\mathrm{I}-$ posttest II pada MAP $(p<0,001),(2)$ perubahan $(\Delta)$ pretest - posttest I dengan perubahan $(\Delta)$ posttest I - posttest II pada denyut jantung $(p=0,003),(3)$ perubahan $(\Delta)$ pretest - posttest I dengan perubahan $(\Delta)$ posttest I - posttest II pada frekuensi pernafasan $(p<0,001)$, dan $(4)$ perubahan $(\Delta)$ 
Anita Setyawati: Pengaruh Foot Massage terhadap Parameter Hemodinamik Non-Invasif

pretest - posttest I dengan perubahan $(\Delta)$ posttest I - posttest II pada saturasi oksigen $(p=0,049)$.

\section{Pembahasan}

Hasil penelitian ini menunjukkan terdapat pengaruh foot massage secara signifikan terhadap penurunan MAP $(\mathrm{p}<0,001)$, penurunan denyut jantung $(p=0,012)$, dan penurunan frekuensi pernafasan $(p<0,001)$. Hasil penelitian ini sejalan dengan pemaparan Smith, Yamashita, Bryant, Hemphill, dan Kutner (2009) tentang hasil penelitian oleh Hayes dan Cox yang menunjukkan bahwa terdapat penurunan secara signifikan pada MAP, denyut jantung, dan frekuensi pernafasan pada 25 pasien di intensive care unit (ICU) saat dilakukan foot massage. Selain itu terdapat hasil penelitian oleh Eimani dan Eshq (2004) yang menunjukkan terdapat penurunan secara signifikan pada MAP, denyut jantung, dan frekuensi pernafasan $(p<0,001)$ pada 46 pasien dengan stroke di ICU setelah dilakukan foot massage. Smith, Yamashita, Bryant, Hemphill, dan Kutner mengungkapkan bahwa pada penelitian oleh Hayes dan Cox (2000), foot massage dilakukan pada pasien di ICU dengan penyakit secara umum. Sementara pada penelitian oleh Eimani dan Eshq (2004), foot massage dilakukan pada pasien di ICU yang sudah dihomogenkan karaketristik penyakitnya yaitu stroke. Namun demikian kedua penelitian tersebut samasama dilakukan di tatanan ICU sebagaimana penelitian ini dilakukan dan menunjukkan hasil yang selaras.

Penelitian ini terdiri dari tiga pengamatan yaitu pretest, posttest I, dan posttest II, yang mana antara pretest - posttest I tidak dilakukan foot massage sementara antara posttest I posttest II dilakukan foot massage. Hal ini ditujukan untuk mengidentifikasi apakah rerata parameter hemodinamik non invasif pada kelompok posttest I - posttest II lebih signifikan jika dibandingkan dengan kelompok pretest - posttest I.

Pada penelitian ini teridentifikasi bahwa rerata MAP pada kelompok posttest I - posttest II lebih signifikan $(\mathrm{p}<0,001)$ jika dibandingkan dengan kelompok pretest - posttest I. Rerata MAP pada posttest I adalah $96,33 \mathrm{mmHg}$ dan pada posttest II adalah 90,18 $\mathrm{mmHg}$. Hal ini menunjukkan bahwa perbedaan antara posttest I dan posttest II berupa penurunan rerata MAP.

Rerata denyut jantung pada kelompok posttest I - posttest II juga lebih signifikan $(\mathrm{p}=0,002)$ jika dibandingkan dengan kelompok pretest dan posttest I. Rerata denyut jantung pada posttest I adalah 100,39 kali per menit dan pada posttest II adalah 96,91 kali per menit. Hal ini menunjukkan bahwa perbedaan antara posttest I dan posttest II berupa penurunan denyut jantung.

Kedua hal di atas seiring dengan hasil rerata frekuensi pernafasan yang lebih signifikan pada kelompok posttest I - posttest II $(\mathrm{p}<0,001)$ jika dibandingkan dengan kelompok pretest posttest I. Rerata frekuensi pernafasan pada posttest I adalah 21,21 kali per menit dan pada posttest II adalah 19,03 kali per menit. Hal ini menunjukkan bahwa perbedaan antara posttest I dan posttest II berupa penurunan rerata frekuensi pernafasan.

Berdasarkan uji Mann-Whitney, lebih jelas lagi hasil penelitian ini menunjukkan terdapat perbedaan secara signifikan antara perubahan $(\Delta)$ pretest - posttest I dengan perubahan $(\Delta)$ posttest I - posttest II pada MAP $(\mathrm{p}<0,001)$, denyut jantung $(p=0,003)$, dan frekuensi pernafasan $(p<0,001)$. Dengan demikian, hasil penelitian ini mengidentifikasikan bahwa rerata MAP, denyut jantung, dan frekuensi pernafasan menurun secara signifikan pada rentang pengamatan yang dilakukan foot massage jika dibandingkan dengan rentang pengamatan yang tidak dilakukan foot massage. Hal ini seiring dengan hasil penelitian Shaban, Amiry, Mehran, dan Kahrary (2004) pada 50 pasien di GICU. Hasil penelitian tersebut menunjukkan terdapat penurunan MAP dan denyut jantung secara signifikan $(\mathrm{p}<0,0011)$ antara 5 menit sebelum foot massage dan selama foot massage; serta penurunan MAP dan penurunan denyut jantung secara signifikan $(p<0,001)$ dan peningkatan saturasi oksigen secara signifikan $(p<0,003)$ antara 5 menit sebelum foot massage dan 5 menit setelah foot massage.

Pada tabel 2 diketahui bahwa perubahan hemodinamik non invasif antara pretest dan posttest I tersebut berupa peningkatan MAP, denyut jantung, dan frekuensi pernafasan. Peningkatan MAP, denyut jantung, dan frekuensi pernafasan ini dapat dipengaruhi oleh 
Anita Setyawati: Pengaruh Foot Massage terhadap Parameter Hemodinamik Non-Invasif

faktor psikologis pasien. Sebelum dilakukan penelitian, pasien diberikan informed consent mengenai foot massage terlebih dahulu. Hal ini memungkinkan pasien merasa cemas terhadap perlakuan yang akan diberikan kepadanya. Sehingga kemungkinan hal ini yang membuat pasien mengalami peningkatan MAP, denyut jantung, dan frekuensi pernafasan antara pretest dan posttest I.

Saat pasien diberikan foot massage, maka pasien merasa mendapatkan sentuhan pada tubuhnya. Teori Jin Shin Jyutsu menyatakan bahwa dinamika sentuhan ini dapat membebaskan sumbatan energi yang selanjutnya dapat menciptakan energi mekanika dalam tubuh (Perry, 2012). Energi mekanika dalam tubuh ini dapat menimbulkan perasaan bahagia, ketenangan, dan secara fisiologis pasien memberikan respon berupa penurunan MAP, denyut jantung, dan frekuensi pernafasan dalam rentang nilai normal. Oleh karena itu, hasil penelitian ini menunjukkan bahwa foot massage bermanfaat bagi tubuh secara fisiologis dan psikologis.

Pada penelitian ini terdapat peningkatan jumlah pasien yang memiliki MAP, denyut jantung, dan frekuensi dalam rentang normal antara sebelum dilakukan foot massage dan setelah dilakukan foot massage. Jumlah pasien yang memiliki MAP normal sebelum dilakukan foot massage adalah $84,9 \%$ dan meningkat menjadi 93,9\% setelah dilakukan foot massage. Jumlah pasien yang memiliki denyut jantung normal sebelum dilakukan foot massage adalah 57,6\% dan meningkat menjadi $66,7 \%$ setelah dilakukan foot massage. Jumlah pasien yang memiliki frekuensi pernafasan normal sebelum dilakukan foot massage adalah $42,4 \%$ dan meningkat menjadi $66,7 \%$ setelah dilakukan foot massage.

Hasil penelitian ini seiring dengan hasil penelitian Kaur, Kaur, dan Bhardwaj (2012) yang menunjukkan terdapat peningkatan jumlah pasien yang memiliki denyut jantung normal dari $66,7 \%$ pasien sebelum foot massage menjadi $70 \%$ pasien setelah foot massage. Pada penelitian yang dilakukan pada 60 pasien di 5 ICU tersebut diketahui terdapat pengaruh foot massage dan reflexology secara signifikan terhadap penurunan denyut jantung pada hari pertama pagi hari $(\mathrm{t}=2,09 \mathrm{p}<0,05)$, hari pertama sore hari $(\mathrm{t}=2,14 \mathrm{p}<0,05)$, hari kedua pagi hari $(\mathrm{t}=2,29 \mathrm{p}<0,05)$, dan hari kedua sore hari $(\mathrm{t}=4,07 \mathrm{p}<0,05)$.

Hasil penelitian ini membuktikan bahwa secara fisiologis foot massage merupakan bagian dari stimulasi kutaneus yang dapat membantu tubuh mencapai homeostasis melalui pengaturan ekstrinsik dan instrinsik aliran darah perifer. Pada pengaturan ekstrinsik, manipulasi foot massage akan menimbulkan aktivitas vasomotor sehingga terjadi relaksasi otot polos dan vasodilatasi pada arteriol (Marley, 2005; Price \& Wilson, 2005; Guyton \& Hall, 2007). Hal ini membuat resistensi perifer menurun dan ditandai dengan penurunan MAP. Selanjutnya pada pengaturan instrinsik, manipulasi foot massage memicu sintesis relaxing factor (nitric oxide) oleh selsel endotel yang melapisi arteriol dan arteri kecil (Price \& Wilson, 2005; Guyton \& Hall, 2007). Nitric oxide kemudian merelaksasikan dinding arteri besar yang mengalir ke atas sehingga secara sekunder melancarkan aliran darah balik vena yang dapat meningkatkan volume sekuncup.

Ketika dilakukan foot massage maka akan menstimulasi serabut saraf parasimpatis yang melepaskan asetilkolin untuk mendekati sel nodal lalu menurunkan frekuensi depolarisasi dan ditandai dengan penurunan denyut jantung (Eimani \& Eshq, 2004; Hudak \& Gallo, 2010). Selanjutnya penurunan denyut jantung dapat menyebabkan waktu pengisian ventrikel yang lebih lama sehingga turut menghasilkan volume sekuncup yang lebih besar dan mengarahkan pada peningkatan curah jantung (Marley, 2005). Curah jantung yang baik dapat meningkatkan sirkulasi darah ke seluruh tubuh termasuk paru sehingga pertukaran oksigen dan karbondioksida menjadi seimbang (Marley, 2005; Guyton \& Hall, 2007). Dengan konsentrasi oksigen dan karbondioksida yang seimbang dalam jaringan, maka akan menunjukkan adanya peningkatan nilai saturasi oksigen dan rangsangan yang terbentuk pada pusat respirasi adalah menurunkan frekuensi pernafasan ke arah normal.

Dalam penelitian ini tidak terdapat pengaruh foot massage secara signifikan terhadap peningkatan saturasi oksigen $(\mathrm{p}=0,150)$. Hal ini dapat disebabkan karena saturasi oksigen pada pretest, posttest I, dan posttest II berada pada nilai yang sudah sama baik dari rentang nilai normal saturasi oksigen (95\% - 100\%), 
Anita Setyawati: Pengaruh Foot Massage terhadap Parameter Hemodinamik Non-Invasif

sehingga setiap perubahan yang didapatkan pada setiap pengamatan tidak berbeda secara signifikan. Saturasi oksigen yang sudah baik pada pretest, dapat disebabkan karena pasien mendapatkan pemberian fraksi inspirasi oksigen $\left(\mathrm{FiO}_{2}\right)$ melalui ventilator. Rerata $\mathrm{FiO}_{2}$ yang diberikan pada 33 pasien dalam penelitian ini adalah 50,30\%. Dengan pemberian $\mathrm{FiO}_{2}$, maka pasien mendapatkan tambahan oksigen untuk diikat dalam hemoglobin dan dibawa ke seluruh tubuh melalui aliran darah lalu dilepaskan ke dalam sel (Price \& Wilson, 2005). Oleh karena itu, saturasi oksigen pada pasien dalam penelitian ini menunjukkan nilai yang baik.

Hasil penelitian ini seiring dengan hasil penelitian Hayes dan Cox yang menunjukkan tidak terdapat pengaruh foot massage secara signifikan terhadap saturasi oksigen pada 25 pasien di ICU (Smith, Yamashita, Bryant, Hemphill, \& Kutner, 2009). Meskipun demikian, dalam penelitian ini diketahui bahwa rerata saturasi oksigen pada pretest adalah 98,30 \%, pada posttest I adalah $98,18 \%$, dan pada posttest II adalah 98,39\%. Hal ini menunjukkan terdapat peningkatan saturasi oksigen antara pretest dan posttest II serta antara posttest I dan posttest II, walaupun tidak berbeda secara signifikan. Selain itu, hasil penelitian ini menunjukkan terdapat perbedaan secara signifikan antara perubahan $(\Delta)$ pretest - posttest I dan perubahan $(\Delta)$ posttest I - posttest II pada saturasi oksigen $(p=0,049)$. Hal ini selaras dengan hasil penelitian Shaban et al. (2004) pada 50 pasien di GICU yang menunjukkan terdapat peningkatan saturasi oksigen secara signifikan antara 5 menit sebelum foot massage dan selama foot massage $(\mathrm{p}<0,001)$ serta antara 5 menit sebelum foot massage dan 5 menit setelah foot massage $(\mathrm{p}<0,003)$.

Pada penelitian lain dengan tujuan untuk mengetahui pengaruh foot massage terhadap peningkatan saturasi oksigen, Moshtaghe, Eimani, Abed, Hosseiny, dan AlaviiMajd (2004) menunjukkan terdapat peningkatan saturasi oksigen secara signifikan pada 46 pasien cerebrovascular accident (CVA) di ICU setelah foot massage $(\mathrm{p}<0,001)$. Hasil penelitian tersebut menunjukan saturasi oksigen pada 10 menit setelah foot massage lebih besar dibandingkan dengan saturasi oksigen pada 10 menit sebelum foot massage; serta saturasi oksigen pada 30 menit setelah foot massage lebih besar dibandingkan dengan saturasi oksigen pada 10 menit sebelum foot massage dan 10 menit setelah foot massage. Hasil serupa juga didapatkan oleh Kaur et al. (2012) bahwa saturasi oksigen pada 60 pasien di ICU meningkat secara signifikan pada hari pertama sore hari $(\mathrm{t}=-4,21 \mathrm{p}<0,01)$ dan hari ketiga pagi hari $(\mathrm{t}=-3,19 \mathrm{p}<0,01)$ setelah dilakukan foot massage.

Berdasarkan pembahasan hasil penelitian di atas, maka pada penelitian ini diketahui bahwa terdapat pengaruh foot massage secara signifikan terhadap penurunan MAP, denyut jantung, frekuensi pernafasan; dan tidak terdapat pengaruh foot massage secara signifikan terhadap peningkatan saturasi oksigen. Pada pasien di ICU kerap kali terjadi multiple organ dysfunction syndrom (MODS) yang tercatat sebagai penyumbang sebagian besar angka kematian di ICU (Boldt, 2002). Meskipun patofisiologi yang tepat dari MODS belum diketahui, namun adanya perubahan hemodinamik yang tidak stabil serta perfusi organ dan mikrosirkulasi jaringan yang menghasilkan hipoksia dianggap memainkan peranan penting dalam terjadinya MODS. Oleh karena itu, interdisiplin di ruang GICU harus dapat melakukan pengelolaan pasien dengan tepat untuk mendapatkan hemodinamik yang stabil pada pasien. Berdasarkan hasil penelitian ini, maka foot massage dapat dijadikan sebagai terapi yang dapat melengkapi terapi farmakologi yang selama ini sudah diberikan pada pasien di ruang GICU untuk mencapai hemodinamik yang stabil.

\section{Simpulan}

Pada penelitian ini telah diketahui bahwa terdapat pengaruh foot massage terhadap parameter hemodinamik non invasif yaitu terdapat pengaruh foot massage terhadap penurunan MAP, terdapat pengaruh foot massage terhadap penurunan denyut jantung, terdapat pengaruh foot massage terhadap penurunan frekuensi pernafasan, tidak terdapat pengaruh foot massage terhadap peningkatan saturasi oksigen.

Disarankan bagi perawat sebagai interdisiplin di ruang GICU maupun tatanan lain dalam lingkup praktik, diharapkan dapat 
Anita Setyawati: Pengaruh Foot Massage terhadap Parameter Hemodinamik Non-Invasif

meningkatkan performa praktik keperawatan mandiri yang dapat melengkapi terapi farmakologi dalam pengelolaan pasien untuk mencapai hemodinamik yang stabil. Salah satu praktik keperawatan mandiri tersebut adalah foot massage yang sebaiknya dilakukan sesuai hasil penelitian ini, khususnya pada pasien pasien di ruang GICU.

\section{Daftar Pustaka}

Boldt,J.(2002).Clinicalreview:Hemodynamic monitoring in the intensive care unit. Critical Care, 6, 52-59. doi:10.1186/cc1453.

Bradley, J.M., Slone, S.A., \& Weiss, H.L. (2012). Jin Shin Jyutsu energy therapy A promising adjunct therapy in reducing pain, stress, and nausea in general cancer population. Retrieved from https://www. jsjinc.net/ns/ups/web-articles/8KMarkeyCanc erCenterPacket.pdf.

Chulay, M., \& Burns, S.M. (2006). AACN essentials of critical care nursing. United State of America: The McGraw-Hill Companies.

Coban, A., \& Sirin, A. (2010). Effect of foot massage to decrease physiological lower leg oedema in late pregnancy: A randomized controlled trial in Turkey. International Journal of Nursing Practice, 16(5), 454-60. doi:10.1111/j.1440-172X.2010.01869.x

Eimani, E., \& Eshq, Z.M. (2004). The effects of foot massage on physiologic indicators in critically ill patients. Iranian Journal of Pharmaceutical Research, 3(2), 36.

Gattinoni, L., \& Carlesso, E. (2013). Supporting hemodynamics: What should we target? What treatments should we use? Critical care (London, England), 17(1), S3. doi:10.1186/cc11502.

Guyton, A.C., \& Hall, J.E. (2007). Buku ajar fisiologi kedokteran (11th Ed.). Terjemahan Irawati Setiawan. Jakarta: EGC.

Haakana,P.(2008). The acute effects of massage on muscle tone piia haakana. University of Jyvaskyla. Retrieved from https://jyx.jyu.fi/ dspace/bitstream/handle/123456789/19902/ CL Haakana.pdf? sequence $=1$.

Hayes, J., \& Cox, C. (2000). Immediate effects of a five-minute foot massage on patients in critical care. Intensive and Critical Care Nursing, 15(2), 77-82. doi:10.1016/S09643397(99)80003-2.

Hudak, C.M., \& Gallo, B.M. (2010). Keperawatan kritis pendekatan holistik. (M. Ester, Ed.) (6th Ed.). Terjemahan oleh Allenidekania, Betty Susanto, Teresa, Yasmin Asih. Jakarta: EGC.

Jevon, P., \& Ewens, B. (2009). Pemantauan pasien kritis. (R. Astikawati, Ed.) (2nd Ed.). Terjemahan Vidhia Umami. Jakarta: Erlangga.

Kaur, J., Kaur, S., \& Bhardwaj, N. (2012). Effect of 'foot massage and reflexology' on physiological parameters of critically ill patients. Nursing and Midwifery Research Journal, 8(3), 223-233.

Kementrian Kesehatan Republik Indonesia. (2011). Petunjuk teknis penyelenggaraan pelayanan intensive care unit di Rumah Sakit. Kementrian Kesehatan RI Direktorat Jenderal Bina Upaya Kesehatan. Retrieved from http:/ www.perdici.org.

Kenny. (2011). The effectiveness of massage therapy, 1-51. Retrieved from http://aamt. com.au/wp-content/uploads/2011/11/AAMTResearch-Report-10-Oct-11.pdf.

Kozier, B., Erb, G., Berman, A., \& Snyder, S.J. (2010). Buku ajar fundamental keperawatan: Konsep, proses, \& praktik (7th Ed., pp. 739810). Terjemahan Pamilih Eko Karyuni, dkk. Jakarta: EGC.

Marley, B. (2005). Massage physiology: Research, effects, indications, contraindications, and endangerment sites. Benefits, contraindications, screening, technique, and special considerations for the massage practitioner (pp. 81-105). Retrieved from www.elsevierhealth.com/media/us/.../ Chapter 05.pdf.

Morton, P.G., \& Fontaine, D.K. (2009). 
Anita Setyawati: Pengaruh Foot Massage terhadap Parameter Hemodinamik Non-Invasif

Critical care nursing (9th Ed.). Wolters Kluwer Health: Lippincott Williams \& Wilkins.

Moshtaghe, E., Eimani, E., Abed, Z.S., Hosseiny, T.A., \& AlaviiMajd, H. (2004). The effects of foot massage on $\mathrm{SpO} 2$ in CVA patients at ICU of Shohadayeh Tajrish Hospital [Farsi]. Journal of Nursing \& Midwifery, 14(45), 56.

Price, S.A., \& Wilson, L.M. (2005). Patofisiologi: Konsep klinis proses-proses penyakit. (H. Hartanto, Ed.) (6th Ed.). Terjemahan Oleh Brahm U. Pendit. Jakarta: EGC.

Puthusseril, V. (2006). "Special foot massage" As a complimentary therapy in palliative care.
Indian J Palliative Care, 12(2), 71-77.

Setyoadi, \& Kushariyadi. (2011). Terapi modalitas keperawatan pada klien psikogeriatrik. Jakarta: Salemba Medika.

Shaban, Amiry, Mehran, \& Kahrary. (2004). Evaluation of immediate effect of foot massage on patient's vital signs in a general intensive care unit [Farsi]. 9(20), 87.

Smith, M.C., Yamashita, T.E., Bryant, L.L., Hemphill, L., \& Kutner, J.S. (2009). Providing Massage Therapy for People with Advanced Cancer : What to Expect. The Journal of Alternative and Complementary Medicine. 13(6), 739-744. 